\title{
33- Şiddet ögeleri bağlamında “Don Kişot” romanı
}

\section{Tuba KAPLAN ALPTEKİN}

APA: Kaplan Alptekin, T. (2021). Şiddet ögeleri bağlamında "Don Kişot" romanı. RumeliDE Dil ve Edebiyat Araştırmaları Dergisi, (25), 529-554. DOI: $10.29000 /$ rumelide.1032437.

$\ddot{\mathbf{O} z}$

Insanlara kötülük yaptığını düşündüğü devler olarak gördüğü yel değirmenleriyle savaşmasıyla bilinen ve her çocuk tarafindan kitabı okunmasa da çizgi filminin mutlaka izlendiği bir kahraman olan Don Kişot, dünya edebiyatında öyküden romana geçişin ilk örneği olarak görülmektedir. Şövalye kitaplarını okumaktan büyük haz alan kahraman, zamanla oradaki olaylarla kendini özdeşleştirmeye başlar ve şövalyeliğini ilan eder. Bu çalışmanın amacı, Miguel de Cervantes'e ait Don Kişot romanında yer alan şiddet ögelerini incelemektir. Nitel araştırma yaklaşımının benimsendiği çalışmanın veri kaynaklarını farklı yayınevlerine ait beş Don Kişot kitabı oluşturmaktadır. Kitaplardan elde edilen veriler betimsel analizle sunulmuştur. Ortaya çıkan bulgular frekanslar hâlinde tablolarda gösterilmiş ve kitaptan örnek cümlelerle desteklenmiştir. Çalışmanın sonucunda Don Kişot romanında şiddet unsurları duygusal, fiziksel, ekonomik ve cinsel şiddet olmak üzere dört temada toplanmıştır. Duygusal şiddet teması alay etmek, hakaret etmek, intikam, küçümsemek ve tehdit olmak üzere beş; cinsel şiddet teması ilişkiye girmek ve çıplaklık olmak üzere iki; ekonomik şiddet teması hırsızlık ve yağmalamak olmak üzere iki; fiziksel şiddet teması dövmek, yaralamak, vurmak, öldürmek ve saldırmak olmak üzere beş kategoride toplanmıştır. Eserde şiddetin yoğun olarak işlendiği ve en fazla duygusal şiddet temasıyla ilgili iletilere yer verildiği tespit edilmiştir. Araştırma sonuçlarından yola çıkılarak incelenen eserlerin ilkokul öğrencileri tarafından okutulmaması önerilmiştir.

Anahtar kelimeler: Don Kişot, şiddet, şiddet ögeleri, fiziksel şiddet, duygusal şiddet

\section{"Don Kişot" novel within the context of violence elements}

\section{Summary}

Don Quixote, who is known for fighting windmills, which he sees as giants that he sees as doing harm to people, and a hero whose cartoons are definitely watched by every child, even if his book is not read, is seen as the first example of the transition from story to novel in world literature. The hero, who takes great pleasure from reading the knight books, begins to identify himself with the events there and declares his knighthood. The aim of this study is to examine the elements of violence in the novel Don Quixote by Miguel de Cervantes. The data sources of the study, in which the qualitative research approach is adopted, are five Don Quixote books belonging to different publishers. The data obtained from the books are presented with descriptive analysis. The resulting findings are shown in the tables as frequencies and supported by example sentences from the book. As a result of the study, the elements of violence in the novel Don Quixote were gathered under four themes as emotional, physical, economic and sexual violence. The five themes of emotional violence are ridicule, insult, revenge, belittlement and threat; two themes of sexual violence are intercourse and nudity; two themes of economic violence are theft and looting; The theme of physical violence is grouped under

Dr. Öğr. Üyesi, Kilis 7 Aralık Üniversitesi, Muallim Rıfat Eğitim Fakültesi, Türkçe Eğitimi Bölümü (Kilis, Türkiye), tubakaplan27@hotmail.com, ORCID ID: 0ooo-0002-7813-0679 [Araştırma makalesi, Makale kayıt tarihi: 13.10.2021kabul tarihi: 20.12.2021; DOI: 10.29000/rumelide.1032437]

Adres $\mid$ Address

RumeliDE Dil ve Edebiyat Araşturmalar Dergisi $\quad$ RumeliDE Journal of Language and Literature Studies

Osmanağa Mahallesi, Mürver Çiçeği Sokak, No:14/8 $\quad$ Osmanağa Mahallesi, Mürver Çiçeği Sokak, No:14/8

Kadıköy - ÍSTANBUL / TÜRKIYE 34714 Kadıköy - ISTANBUL / TURKEY 34714

e-posta: editor@rumelide.com e-mail: editor@rumelide.com,

tel: +90 505 7958124, +90 2167730616 phone: +90 505 7958124, +90 2167730616 
five categories as beating, injuring, hitting, killing and attacking. It has been determined that violence is handled intensely in the work and messages related to the theme of emotional violence are mostly included. As a result of the research, it has been suggested that the book Don Quixote, whose target audience is children, should be purified from the elements of violence and published.

Keywords: Don Kişot, violence, elements of violence, physical violence, emotional violence

\section{Giriş}

Günümüzde şiddet olaylarının her geçen gün daha da arttığı tartışılan bir konudur. Gündemi sık sık meşgul eden bir konu olması akıllara “Geçmişte şiddet olayları yaşanmadı mı?” sorusunu getirmektedir. Teknolojinin olmadığı ya da bu kadar gelişmediği bir dönemde insanların şiddetten haberdar olmaları oldukça zordur. Günümüzde kitle iletişim araçlarından dolayı şiddet, daha görünür duruma gelmiştir ve şiddet haberleri sosyal medya mecraları vesilesiyle çok hızlı bir şekilde yayılmaktadır.

Hayatın içine bu denli yerleşen şiddetin tanımına bakılacak olursa "Bir kişi ya da grubun başkalarına karşı fiziksel olarak zarar vermesi. Patlayıcı olması ve yaralama, yok etme amacını gütmesi nedeniyle saldırganlık eyleminin uç noktası.” (Abay ve Tuğlu, 2000: 22) şeklinde tanımlanırken Akkaş ve Uyanık tarafından bir hareketin bir gücün derecesi, sertlik; karşıt görüşte olan kişileri inandırma veya uzlaştırmak yerine kaba kuvvet kullanma; duygu ve davranışta aşırılık (2016: 32) şeklinde izah edilmektedir. Mavili Aktaş’a göreyse (2006: 13) "Bireyin bedensel ve ruhsal açıdan zarar görmesine, yaralanmasına ve sakat kalmasına neden olan bireysel ve toplu hareketlerin tamamı"dır. Şiddetle ilgili olarak araştırmacılar tarafından farklı tanımlar yapılsa da tanımların ortak noktası şiddete maruz kalan kişinin gerek fiziksel gerekse psikolojik olarak zarar görmesi ve tüm bunların hayat kalitesini düşürmesidir.

Şiddet olaylarının gündemde konuşulan bir konu olması, çevremizde şiddet olaylarına tanık olmak ailelerin çocukları için endişelenmelerine neden olmaktadır. Öyle ki çocukların izlediği çizgi filmlerde hatta okuduğu kitaplarda bile şiddet ögelerine rastlamak olası bir durum hâline gelmiştir. Hedef kitlesi çocuk olan eserlerde şiddetin yer alması çocuk edebiyatı eserlerinin amacının dışına çıkmaktadır. Çünkü çocuk edebiyatı eserlerinin amacı çocuğun gelişimine büyük ölçüde katkı sunmak, onlara okuma sevgisi ve alışkanlığı kazandırmak, gelecekte karşılaşmaları muhtemel olaylar ve kişiler hakkında deneyim kazanmalarına yardımcı olmaktır (Yılmaz ve Destegüloğlu, 2019: 416). Bu nedenle çocuklara kitap seçerken çocuğun ilgi alanına giren, rol model olarak seçebileceği kahramanlardan oluşan ve onu olumlu yönden etkileyen kitaplar seçmek gerekmektedir, bazı kitaplar içinde taşılığı olumsuz iletilerle çocuklara kötü örnek olabilmektedir. Çünkü çocukları şiddete yönlendirebilecek türdeki medya unsurlarından biri de çocuk kitaplarıdır (Yavuzer, 2009: 243). Bu kitaplarda çocuğu şiddete teşvik edecek iletilere rastlanmaktadır. Bu sebeple de çocuklara sunulacak her türlü edebi ürünün çok dikkatli bir kontrol sürecinden geçirilmesi gerekmektedir (Demirel ve Kökçü, 2019: 150).

Okudukları kitaplardaki olumlu ve olumsuz iletilerin çocukları etkilediği gerçeğinden yola çıkarak kitapların çocuğa göre olmasının büyük önem taşıdığı söylenebilir. Çocuğa görelik ilkesi çocuk edebiyatı açısından önemli bir kavramdır ve çocuk edebiyatı eserlerinin seçiminde önemli rol oynamaktadır. Mustafa Ruhi Şirin'e göre; çocuklar için yapılacak edebiyat, çocuğun büyüme ve gelişme çağlarına, psikolojisine, sözcük ve kavram ilgisine, algılama dünyasına uygun bir duyarlılık taşımalıdır (1998: 19). Dilidüzgün (1996: 27), çocuğa göreliği, çocuk gerçekliğini ele alma ve onun dünyasına paralel bir dünya kurgulamak olarak kabul eder. Çer (2016a: 86), çocuğa göreliği; dilin ve resmin anlatım gücü, karakterin 
nitelikleri, eylem ve davranışları, iletilerin türü, konunun özellikleri, kurgunun düzeyi; kitabın ve görsellerin boyutu, kapağın dikkat çekici olması, kâğıdın ve cildin kalitesi, sayfa düzeni, harflerin türü, görsellerin niteliği; kurgudaki mantık yanlışlıkları, toplumsal cinsiyetçi yaklaşım, geleneksel yargılar, denetimci ve baskıcı anlayış, kaderciliği ve boş inançları onaylayan anlayış, siyasal öğüt ve emirler, araştırmayı körelten, girişimciliği engelleyen durumlarla ilgili çocukla kitap arasındaki ilişkide, kitabın niteliklerinin hem yazın olma ilkelerine hem sanatçı duyarlığına hem de çocuk gerçekliğine uygun olmasını sağlayan tüm değişkenlerin toplamı olarak değerlendirir. Çocuğa görelik, bir eserin çocukların ilgi ve ihtiyaçlarını, eğilimlerini göz önünde bulunduran konuları işleme, yaş dönemlerine göre değişen özelliklerini dikkate alma, biçimsel niteliklerde olma, dil ve anlatım yönünden çocukların rahatça anlayabilecekleri düzeyde olma, çocukların duygu ve düşüncelerinin gelişimine katkı sağlaması özelliklerini taşımasıdır(Sezer, 2020; Küçük, 2005).

Araştırmacılar çocuğa göreliğin çocuk edebiyatındaki önemini ve niteliklerini yaptıkları tanımlarda her hangi bir tür belirtmeden ortaya koymuşlardır. Güleryüz ise (2003: 261), çocuğa göre olan bir öykünün taşıması gereken özellikleri şu şekilde sıralamıştır:

- Öyküler, çocukların gelişim seviyesine uygun olmalıdır.

- Çocukların ilgi ve ihtiyaçlarına uygun olmalıdır.

- İçeriksel örüntü uygun olmakla birlikte doğrudan ders vermek yerine aktarılan mesajı çocuğun kendisinin bulması sağlanmalıdır.

- Dili anlaşlır olmakla birlikte çocuğun dil evrenini geliştirmelidir.

- Çocuğun duygularına ve çocuk gerçekliğine uygun olmalıdır.

- Çocuğun estetik bilincini geliştirmelidir

- Doğrudan mesajlarla değil de bilinçaltına gönderdiği mesajlarla çocukta okuma isteği uyandırmalıdır.

Güleryüz (2003), çocuklar için öykülerin önemine dikkat çekerken çocuğa göreliğin kapsamının genişliğini de ortaya koymuştur. Okuma alışkanlığı kazandırmak açısından edebiyat ürünlerinin katkısı büyük olmakla birlikte, araştırmacı bu noktada öykünün önemine temas etmiştir.

Dünya edebiyatında öyküden romana geçişin ilk örneği olarak kabul edilen Don Kişot, çocuklar tarafından çok sık okunan eserlerden biridir. Çocukların ilgisini çekebilecek özelliklere sahip Don Kişot'un içeriği şöyledir: Don Kişot'un en büyük hobisi şövalye romanları okumaktır ve kitaplardaki dünyaya kendisini o kadar çok kaptırır ki kendisini şövalye olarak görmeye başlar. En büyük amacı okuduğu kitaplardaki şövalyelerin yaptığı gibi dünyadaki haksızlığı ve kötülüğü ortadan kaldırmak ve insanların mutlu olmasını sağlamaktır. Zayıf ve çelimsiz atı Rocinante'ye biner ve çeşitli vaatlerle yanına çektiği Sanscho Panza'yla yolculuğa başlar. Hayal dünyasında yaşayan kahraman, yel değirmenlerini insanlara zarar veren devler olarak görür ve onlarla savaşmaya karar verir. Bu savaştan zararlı çlkan Don Kişot, bu süreçte birçok macera yaşar ve sonra köyüne döner, ölümüne yakınken aklı başına gelse de artık her şey için çok geçtir.

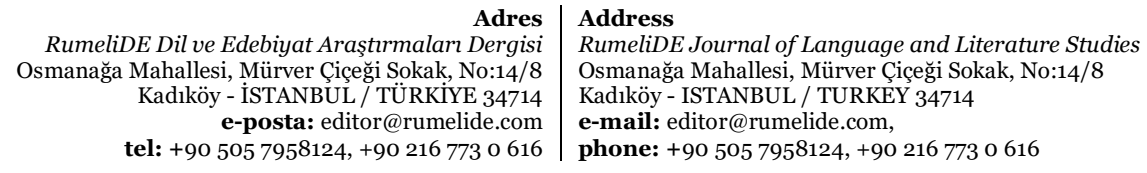


Alanyazındaki Don Kişot'la ilgili çalışmalar incelendiğginde eserdeki şiddet iletilerine ilişkin herhangi bir çalışma yapılmamış olması bu çalışmanın ortaya çıkmasında etkili olmuştur. Eseri şiddet ögeleri bağlamında değerlendirerek öğretmenlerin "Bu kitabı çocuklara okutmalı mıyım ya da okutmamalıyım?” sorusunun cevabını bulmasına yardımcı olacağından dolayı çalışmanın alana katkı sağlayacağı düşünülmektedir. Bu çalışmada eseri şiddet ögeleri bağlamında incelemek amaçlanmış ve bu temel amaç doğrultusunda şu sorulara cevap aranmıştır.

1. Don Kişot romanında hangi şiddet iletileri geçmektedir?

2. Don Kişot romanında şiddet türlerinden hangisi daha yoğun kullanılmıştır?

\section{Yöntem}

\section{Araştırmanın modeli}

Çalışma, nitel araştırma yöntemlerinden doküman analizi ile gerçekleştirilmiştir. Doküman analizi, araştırılması hedeflenen olgu veya olgular hakkında bilgi içeren yazılı materyallerin analizini kapsar (Ylldırım ve Şimşek, 2011: 187).

\section{Veri toplama aracı}

Çalışmada incelenen Don Kişot kitaplarının seçiminde ölçüt örnekleme yöntemi kullanılmıştır. Bu örnekleme yöntemindeki temel anlayış önceden belirlenmiş bir dizi ölçütü karşllayan bütün durumların çalışılmasıdır (Yıldırım ve Şimşek, 2011: 112). Çalışmada beş yayınevi tarafından basılan Don Kişot kitapları incelenmiştir, farklı yayınevlerinde şiddet unsurlarına ne şekilde ve ne kadar yer verildiğini tespit etmek amaçlandığı için örneklem sayısı fazla tutulmuştur. Kitaplar seçilirken baskı yılının günümüze yakın olmasına ve incelemesinin kolay olması için sayfa sayısının fazla olmamasına dikkat edilmiştir.

Özyürek ve Masalperest yayınlarında anlatılan konuya ilişkin resimlere yer verilmezken Fark, Erdem ve Arkadaş yayınlarında içerikle ilgili resimler vardır. Erdem yayınlarında kitabın hitap ettiği yaş grubu belirtilirken diğerlerinde yoktur.

İncelenen eserlere ilişkin bilgiler Tablo 1'de sunulmuştur.

Tablo 1. Eserlere ilişkin bilgiler

\begin{tabular}{|c|c|c|c|c|c|}
\hline Kitap İsmi & Yayınevi & Çevirmen & Yllı & Sayfa Sayısı & Kisaltmalar \\
\hline Don Kişot & Fark Yayınları & $\begin{array}{l}\text { Fatma Burcu } \\
\text { Uzunoğlu }\end{array}$ & 2019 & 86 & Ç1 (Çeviri 1) \\
\hline Don Kişot & $\begin{array}{l}\text { Erdem } \\
\text { Yayınları }\end{array}$ & Adem Yaşar & 2019 & 96 & Ç2 (Çeviri 2) \\
\hline Don Kişot & $\begin{array}{l}\text { Özyürek } \\
\text { Yayınları }\end{array}$ & $\begin{array}{l}\text { Kerim } \\
\text { Çetinoğlu }\end{array}$ & 2019 & 112 & Ç3 (Çeviri 3) \\
\hline Don Kişot & $\begin{array}{l}\text { Arkadass } \\
\text { Yayınevi }\end{array}$ & Ali Aydoğan & 2021 & 93 & Ç4 (Çeviri 4) \\
\hline Don Kişot & Masalperest & $\begin{array}{l}\text { Ceren } \\
\text { Cevahir } \\
\text { Gündoğan }\end{array}$ & 2020 & 136 & Ç5 (Çeviri 5) \\
\hline
\end{tabular}

Adres
RumeliDE Dil ve Edebiyat Araştırmaları Dergisi Osmanağa Mahallesi, Mürver Çiç̧̌̆i Sokak, No:14/8 Kadıköy - ISTANBUL / TÜRKIYE 34714 e-posta: editor@rumelide.com tel: +90 $5057958124,+902167730616$
Address

RumeliDE Journal of Language and Literature Studies

Osmanağa Mahallesi, Mürver Çiçeği Sokak, No:14/8

Kadıköy - ISTANBUL / TURKEY 34714

e-mail: editor@rumelide.com,

phone: +90 505 7958124, +90 2167730616 


\section{Verilerin analizi}

Eserler, araştırmacı tarafından ilk olarak fikir sahibi olmak amacıyla okunmuş ve önemli görülen yerlerin altı çizilmiştir. Ardından eserler daha dikkatli okunarak eserlerdeki şiddet unsurları fişlenmiştir. Elde edilen veriler betimsel analizle sunulmuştur. Betimsel analizde amaç, elde edilen bulguları düzenlenmiş ve yorumlanmış biçimde okuyucuya sunmaktır (Yıldırım ve Şimşek, 2011: 224). Araştırmacının dışında bir Türkçe eğitim uzmanı tarafından rastgele seçilen kitaplardan birinin incelemesi yapılmıştır ve veriler karşılaştırılmıştır. Çalışmanın güvenirliğini sağlamak amacıyla Miles ve Huberman'ın (1994) formülü kullanılmıştır. Buradaki amaç iki kodlayıcının yapmış olduğu kodlamaların örtüşüp örtüşmediğine bakmaktır. İki kodlayıcı arasındaki kodlama güvenirliğinin .83 olduğu tespit edilmiştir. Ulaşılan sonuç, kodlamaların güvenilir olduğunu göstermektedir.

İncelenen eserlerde şiddet unsurları duygusal, fiziksel, ekonomik ve cinsel şiddet olmak üzere dört temada toplanmıştır. Şiddet unsurları ve şiddet ögelerinin geçtiği cümlelerin sıklıkları tablolarda sunulmuştur. Ayrıca eserlerden doğrudan aktarım cümlelerine yer verilmiştir.

\section{Bulgular}

\section{Duygusal şiddet temasında yer alan kategoriler}

Duygusal şiddet temasında yer alan kategoriler, Tablo 2'de sunulmuştur.

Tablo 2. Duygusal şiddet temasında yer alan kategoriler

\begin{tabular}{ll}
\hline Tema & Kategori \\
\hline & Alay etmek \\
& Hakaret etmek \\
Duygusal Şiddet & Intikam \\
& Küçümsemek \\
& Tehdit etmek \\
\hline
\end{tabular}

Alay etme unsuruna ilişkin bulgular, Tablo 3'te sunulmuştur.

Tablo 3. Alay etme unsuruna ilişkin bulgular

\begin{tabular}{lll}
\hline \multirow{3}{*}{ Alay etmek } & Eser & $\mathrm{f}$ \\
\cline { 2 - 3 } & Ç1 & 6 \\
& Ç2 & 4 \\
Ç3 & - \\
Ç4 & 1 \\
Toplam & Ç5 & 1 \\
& & 12 \\
\hline
\end{tabular}

Tablo 3'te eserlerde yer alan alay etme iletilerine ilişkin bulgulara yer verilmiştir. Alay etme iletisine yönelik en fazla ileti taşıyan eser Çı'dir. Bunu sırasıylaÇ2, Ç4 ve Ç5 izlerken alay etme iletisine Ç3’te hiç yer verilmediği tespit edilmiştir. Çocuklar tarafından okunan kitaplarda gerek insanların kıyafetleri

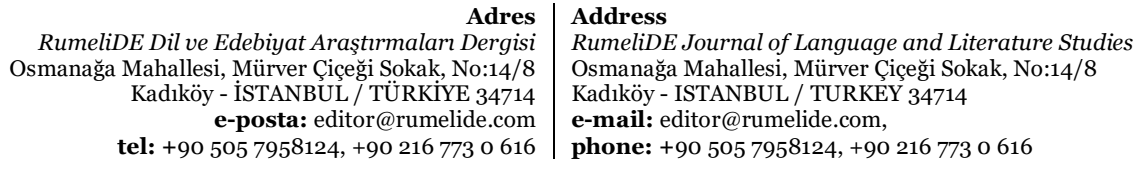


gerekse de davranışlarıyla alay edilmesi olumsuz bir öge olarak görülmektedir. Okuduğu kitaptaki karakterleri kendisine rol model alma eğiliminde olan çocuğun bu davranışın birden fazla kişi tarafından yapılmasını olumsuz bir durum olarak görmemesine neden olacaktır. Don Kişot da çocuklar tarafından sıklıkla okunan eserlerden biridir ve eserin bu yönüyle çocuklar için uygun olmadığı söylenebilir. Alay etme iletisiyle ilgili bazı örnekler şöyledir:

İnsanların kıyafetleri ve davranışları alay unsuru olabilmektedir.

Konuşması, giysileri ve hareketleri öyle gülünçtü ki, kadınlar kahkahalar atarak onunla alay etmeye başladılar (Ç1: 8).

Kahkaha seslerini duyan han sahibi, ne olduğunu anlamak için dışarı çıktı. Karşısında, zavallı bir ata binmiş olan, döküntü bir zırh içindeki Don Kişot’u görünce gülmemek için kendini zor tuttu (Ç1: 8).

Kadınlar konuşmanın saçmalı̆̆ ve adamın tuhaf giyimi karşısında gülmekten kendilerini alamadılar (Ç5: 8).

İnsanlar saflıklarından yararlanılarak kandırılmaktadır ve bu gülme, alay unsuru olabilmektedir.

Tuhaf davranışlarma bir anlam veremeyen han sahibi, ona şatonun avlusuna gitmesini ve şafak sökene kadar atıyla beklemesini buyurdu. Ertesi gün onu şövalye ilan edecekti. O gittikten sonra da arkasından katıla katıla güldü (Ç1: 9).

Alay etmek kimi zaman toplu olarak yapılmaktadır.

Han sakinleri pencereden ona bakıp gülü̧̈üyorlardı (Ç1: 9).

Az önce sataştı̆̆ adamlar ise onunla alay ettikten sonra gülüşmeler eşliğinde yollarma devam etmişlerdi (Ç1: 13).

Kadınlar onun zararsız bir kaçık olduğunu anlayarak gülüştüler (Ç2: 10).

Dük'le Düsses birbirlerine bakıp hikâyeyi bildikleri için gülüştüler (Ç2: 91).

Herkes saatlerce onları anlatıp kahkahalarla güldü (Ç2: 93).

Yabancının sözleri kadınlara çok gülünç geldi. Onun bir deli olduğunu düşünerek, kaçmaktan vazgeçip kahkahalar atarak gülmeye başladı (Ç4: 11).

Don Kişot, çevresindekilerin onunla alay ettiklerini anlayamayacak kadar saf biridir.

Sanşo başın çevirip kikir kikir gülerken Don Kişot hâlâ sevgili Dülsia'sinın peşinden yaşl gözlerle bakıyordu (Ç2: 51).

Hakaret unsuruna ilişkin bulgular, Tablo 4'te sunulmuştur.

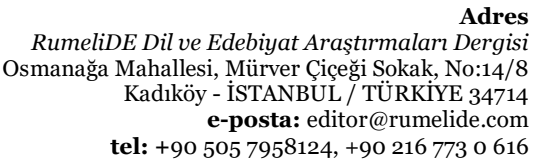

dres

RumeliDE Journal of Language and Literature Studies Osmanağa Mahallesi, Mürver Çiçeği Sokak, No:14/8

Kadıköy - ISTANBUL / TURKEY 34714

e-mail: editor@rumelide.com,

phone: +90 $5057958124,+902167730616$ 
Tablo 4. Hakaret unsuruna ilişkin bulgular

\begin{tabular}{lll}
\hline & Eser & $\mathrm{f}$ \\
\cline { 2 - 3 } Hakaret Etmek & Ç1 & 2 \\
Ç2 & 15 \\
Ç3 & 13 \\
Ç4 & 8 \\
Ç5 & 3 \\
Toplam & & 41 \\
\hline
\end{tabular}

Tablo 4'te eserlerde yer alan hakaret iletilerine ilişkin bulgulara yer verilmiştir. Hakaret etme iletisine yönelik en fazla ileti taşıyan eser Ç2'dir. Bunu sırasıyla Ç3, Ç4 ve Ç5 ve Ç1 izlemektedir. Kitaplarda yoğun şekilde (41) hakaret edici sözlerin yer alması eserin olumsuz yönünü oluşturmaktadır. "Diğer kadınlar da birbirinden ağır hakaretlerde bulunduktan sonra homurdanarak çekip gitti.” (Ç4: 48) ifadesinden yola çıarak çocuklar, insanların birbirlerine hakaret etmelerini olağan bir durum olarak düşünebilirler. Hakaret edilen kişiye söylenen sözler çocuğun psikolojisini olumsuz olarak etkileyerek öz güvenini yitirmesine, çekingen olmasına, içine kapanmasına neden olabilmektedir. Kitaplarda Don Kişot yardımcısı Sancho Panza’yı azarladığında ve hakaret ettiğinde Sancho'nun üzüldüğg̈ hissettirilmiştir. Aşağıda hakaret etmekle ilgili örnek cümlelere yer verilmiştir:

"Zavall mahlûk!" dedi Don Kişot ve hiçbir ödeme yapmadan atına bindi (Ç1: 26).

Adi yaratıklar! diyerek onlara emirler verdi (Ç1: 62).

Şeytan surath iblis büyücüler (Ç2: 28).

Çek kılıcın namussuz alçak, hain, kalleş! (Ç2: 39).

Bir daha miğferime tas diye hitap edecek olursan ebediyen vali olamazsm cahil budala (Ç2: 39).

Bu altın miğferi birtakım budalalar anlaşılan başka amaçlar için kullanmıştır (Ç2: 39).

Bunlar zannettiğimden de güçlü düşmanlar. Ancak iblisler bu kadar hızh hareket edebilir. Fakat kalkanımı ne kadar iyi kullandığımı bilemez bu alçaklar (Ç2: 43).

Emin misin sersem, bunlar bana cılız eşeklere binmiş üç zavall köylü kadın gibi görünüyor (Ç2: 5o).

Brrakın o küstah aslanları da derslerini vereyim (Ç2: 55).

İşin bitmedi korkak herif (Ç2: 6o).

Kurtarılması işi bana düşüyor, anladın mı geri kafah? (Ç2: 69).

Sen bizim işimize niçin karışıyorsun be bunak adam, diyerek Sanşo'yu bir güzel dövdüler (Ç2: 75).

Bir daha asla böyle zevzeklikler etme olmaz mı?(Ç2: 77).

Onların aptallkkları yüzünden böyle durumlara düştüğümüz oluyor (Ç2: 79).

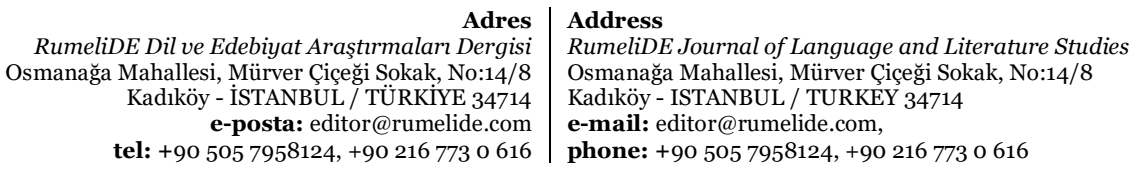


Aptal doktor, beni açllktan öldürecek (Ç2: 86).

Namussuz alçaklar, bu hakaretinizi kanınıza ödeyeceksiniz (Ç2: 16).

Böyle sözlerle beni kandıramazsınız. Namussuz alçaklar!.. (Ç2: 28).

Alçak namussuzlar, daha ben karaya ayak basmadan saldırmaya başlyyorsunuz ha! (Ç2: 73).

Çok utanmıştı ve içinden Sancho'ya küfredip duruyordu (Ç3: 87).

Kaçmayın alçak yaratıklar! diye bağırdı (Ç3: 18).

Siz hem aptal hem de kötü hancısınız, dedi Don Kişot (Ç3: 29).

O lanet iksiri kendinize saklayın (Ç3: 30).

Beni dünyaya getiren şanssız anaya lanet olsun (Ç3: 34).

Sancho, sen yeryüzündeki en aptal şeysin (Ç3: 44).

Sancho, kaç kere söyledim, amma gevezesin! Aptallğına bakmadan kurnazlık ediyorsun (Ç3: 47).

Burada ne işin var senin, serseri adam! diye bağırdı (Ç3: 64).

Adalar boğazına sarılır da ölürsün, pis herif! diye bağırdı (Ç3: 64).

Bana bak serseri herif, şu kafesleri hemen şimdi, şu dakikada açmazsan, bir vuruşta arabanm içine sererim seni!, diye bağırdı (Ç3: 8o).

Sancho, sen ne budala, soytarı adammışsın! Dedi (Ç3: 90).

Şunu da unutma soytarn (Ç3: 9o).

O deli, sen daha deli (Ç4: 19).

Saçmaladığın yeter kaçık herif! (Ç4: 32).

Uyan hey koca tembel! (Ç4: 38).

Diğer kadınlar da birbirinden ağır hakaretlerde bulunduktan sonra homurdanarak çekip gitti (Ç4: 48).

Şeytanın çocukları, tümünüz gelin isterseniz! (Ç4: 72).

Ey nankör hizmetkârtm, para kesem sende değil mi? (Ç4: 76).

Bilgisiz olduğunu biliyordum ama bu kadar aptal olduğunu bilmiyordum doğrusu. Beyninde zerre kadar akıl olsaydı, işin sonuna yaklaştığımızı anlardın (Ç4: 77).

Söylediğiniz gibi aptal biriyim ben (Ç4: 77).

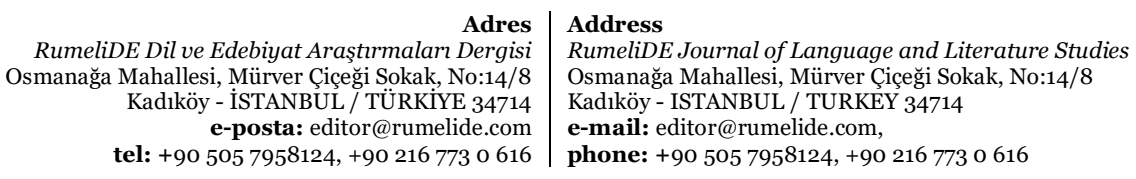


"Sen zavallı aptahn tekisin" dedi Don Kişot (Ç5: 39).

"Sen bir kedi, fare, bir rezilsin" diye bağırdı Don Kişot (Ç5: 56).

Ey korkak yaratık! (Ç5: 87)

İntikam unsuruna ilişkin bulgular, Tablo 5’te sunulmuştur.

Tablo 5. İntikam unsuruna ilişkin bulgular

\begin{tabular}{lll}
\hline & Eser & $\mathrm{f}$ \\
\cline { 2 - 3 } İntikam & Ç1 & 2 \\
Ç2 & 1 \\
Ç3 & 1 \\
Ç4 & 1 \\
Ç5 & - \\
Toplam & & 5 \\
\hline
\end{tabular}

Tablo 5’te eserlerde yer alan intikam iletilerine ilişkin bulgulara yer verilmiştir. İntikam iletisine yönelik en fazla ileti taşıyan eser Çı'dir. İntikam iletisine ilişkin toplamda 5 veri tespit edilmiştir. Bunu sırasıyla Ç2, Ç3 ve Ç4 izlemektedir, Ç5’te ise intikam iletisine rastlanmamıştır. İncelenen eserlerde yoğun olmasa da intikam (5) iletisinin yer alması eserin olumsuz yönünü oluşturmaktadır. Çünkü intikam eserlerde kutsal bir görev olarak işlenmiş ve intikamın alınması gereken bir zorunluluk olarak işlenmesi çocukların gerek ailesine gerekse de arkadaşlarına karşı affedici olmasını engellemesine neden olacaktır. $\mathrm{Bu}$ yönüyle de çocukları olumsuz olarak etkilemektedir. Aşağıda intikamla ilgili örnek cümlelere yer verilmiştir:

Don Kişot, han sahibine "Sizi inciten insanlardan intikamınızı almak, bir şövalye olarak benim görevimdir.” dedi (Ç1: 25).

Bir gün bunun öcünü alacağıma ant içiyorum (Ç4: 52).

İntikamını kişinin kendisinin alması gerektiği sezdirilmiştir.

Han sahibi "Ĕ̆er biri beni incitirse ondan kendi intikamımı kendim alabilirim.” dedi (Ç1: 26).

İntikam kutsal bir görev olarak işlenmiştir.

Hemen onun hakkmdan gelmek en kutsal görevindir, bunu da unutma (Ç2: 27).

İntikamın alınmadığı takdirde daha kötü şeylere sebep olabileceği düşünülmektedir.

İntikamın alacağı kötülükler, onaracağı hatalar, cezasını vereceği haksızlılar ve ödeteceği o kadar borç vardı ki bekleyip bunları gerçekleştirmezse doğacak acılardan kendini sorumlu tutacaktı (Ç3: 9).

Küçümsemek / küçük görmek unsuruna ilişkin bulgular, Tablo 6'da sunulmuştur.

Tablo 6. Küçümsemek / küçük görmeye ilişkin bulgular

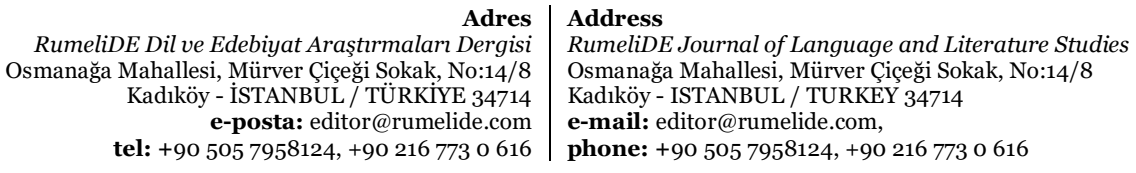




\begin{tabular}{lll}
\hline & Eser & $\mathrm{f}$ \\
\cline { 2 - 3 } Küçümsemek & Ç1 & 1 \\
Ç2 & 13 \\
Ç3 & 4 \\
Ç4 & 4 \\
Ç5 & 1 \\
Toplam & & 23 \\
\hline
\end{tabular}

Tablo 6'da eserlerde yer alan küçümsemek/ küçük görmek iletilerine ilişkin bulgulara yer verilmiştir. Küçümsemek iletisine yönelik en fazla ileti taşıyan eser Ç2'dir. Bunu sırasıyla Ç3, Ç4, Ç1 ve Ç5 izlemektedir. İncelenen eserlerde yoğun olarak küçümsemek/ küçük görmek (23) iletisinin yer alması eserin olumsuz yönünü oluşturmaktadır. Çünkü incelenen eserlerde insanların maddi durumları, fiziksel özellikleri, köylü olmaları, isimleri küçük görülmeleri ve dışlanmaları için sebep olarak görülmektedir. Özellikle daha küȩük yaş gruplarındaki çocukların bunları çevrelerinde uygulamaya çalışmaları mümkün olmaktadır. Bu yönüyle eserin olumsuz özellikler barındırdığı söylenebilir. Aşağıda küçümsemeyle ilgili örnek cümlelere yer verilmiştir:

Küçümseme eylemi kişinin yüzüne aleni bir şekilde yapılmaktadır.

“Sen ne anlarsın!" dedi, Don Kişot, "Bu çok ünlü ve kıymetli bir miğfer.” (Ç1: 34).

Senin gibi asil olmayanlar nasıl benimle böyle konuşmaya cesaret edebilir? (Ç2: 29).

Senin gibi kültürsüz birini fazla azarlayacak değilim (Ç2: 39).

Açılayayım cahil adam (Ç2: 69).

Kaba ve bilgisiz insan olduğunu her yerde belli etme (Ç3: 90).

Senin kaba bir köylüden, şarlatan bir budaladan başka bir şey olmadiğını anladıkları gün, bana da bir yalancl, düzmece şövalye gözüyle bakacaklar? (Ç3: 91).

Hatırın kırmak istemiyorum ama sen de çok oluyorsun be cahil adam! (Ç4: 41).

Bazen cahil cahil konuşuyorsun (Ç4: 70).

İnsanların isimleri küçümsenecek bir unsur olabilmektedir.

Aldonzo mu? Aman ne yakışıksız bir ad. Tam köylü adı (Ç2: 9).

İlk kez senden duyuyoruz böyle matrak bir ismi (Ç2: 53)

Kız güzeldi, ama soylu bir bayana yakışan ada sahip değildi (Ç4: 8).

İnsanların sadece köylü olmaları küçümsenmeleri için yeterli bir sebeptir.

Kartm böyle bir rütbeye layık biri değil. Basit bir köylüdür o. (Ç2: 24).

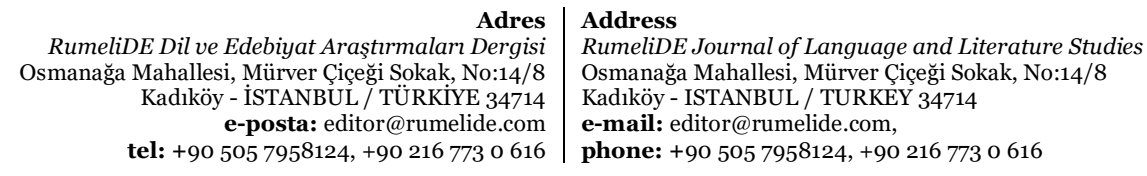


Don Kişot’un Dülsia diye hitap ettiği kadın, tam bir köylü hırçınhğıyla yoluna devam etmek istedi (Ç2: $50-51)$.

Dülsia’mı büyücülerin çirkin bir köylü kadını hâline getirmesine nasıl göz yumdun? (Ç2: 51).

Sayelerinde nice güzel vakit geçirdiğimiz şu iki saf köylü artık gidiyorlar. Doğrusu sıkıcı hayatımızı budalalıklarıyla bir hayli neşelendirmişlerdi (Ç2: 92).

Zihninde tasavvur ettiği o güzellik timsalinin yerine oldukça çirkin, yamyassı burunlu, yuvarlak yüzlü bir köylü kadını gören şövalye ağzını açmaya cesaret edemiyordu (Ç3: 75).

Bu hainler, Dulcinea’yı yalnız köylü kadını kılığına sokmakla kalmamış, soylu ve güzel kadınlara özgü olan özelliğini de değiştirmişler. Soylu ve güzel kadınlar mis gibi kokar; oysa Dulcinea’yı kısrağına bindirmek için yanına yaklaştığımda burnuma keskin bir sarımsak kokusu geldi (Ç3: 76).

Söylemesi üzücüdür ama ona büyü yapıldı ve çirkin bir köylü kızına dönüştürüldü (Ç5: 94).

Maddi durumun yetersiz olması küçümsenme nedenidir.

Bunlar berbat bir kulübede kalıyorlardı (Ç2: 35).

İnsanlar sadece sözlerle değil bakışlarla da küçük görülebilir.

Don Kişot, başımı hafifçe çevirip Sanşo'ya budalalara bakıldı̆̆ı gibi baktı (Ç2: 38).

Don Kişot’sa her zamanki gibi etrafina küçümseyerek bakıyor ve şaşkın şaşkın kendini süzenlerden dolayı gurur duyuyordu (Ç2: 62).

İnsanlar fiziksel özelliklerinden dolayı da küçümsenmektedir.

Patates surath, domates burunlu, şaşı bakışl kadın ne yapacağını şaşırdı (Ç2: 5o).

Zayıf, çelimsiz adamı küçümsediğine bin pişmandı (Ç4: 32).

Tehdit unsuruna ilişkin bulgular, Tablo 5'te sunulmuştur.

Tablo 7. Tehdit unsuruna ilişkin bulgular

\begin{tabular}{lll}
\hline & Eser & $\mathrm{f}$ \\
\cline { 2 - 3 } Tehdit & Ç1 & 11 \\
& Ç2 & 11 \\
& Ç3 & 12 \\
& Ç4 & 5 \\
Toplam & Ç5 & 7 \\
\hline
\end{tabular}

Tablo 7'de eserlerde yer alan tehdit iletisine ilişkin bulgulara yer verilmiştir. Tehdit iletisine yönelik en fazla ileti taşıyan eser Ç3’ür. Tehdit iletisine ilişkin toplamda 46 veri tespit edilmiştir. Bunu sırasıyla Ç1, Ç2, Ç5 ve Ç4 izlemektedir. İncelenen eserlerde yoğun olarak tehdit (46) iletisinin yer alması eserin

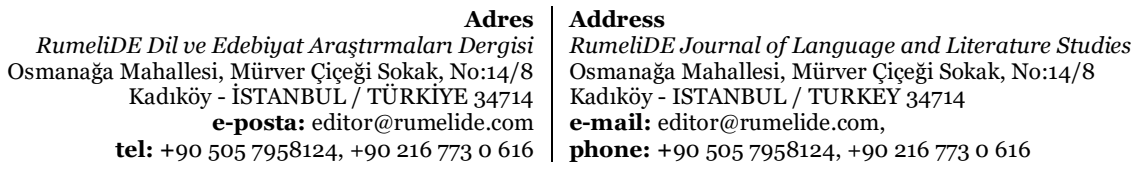


olumsuz yönünü oluşturmaktadır. Çünkü incelenen eserlerde öfke anında ortaya çıkması normal bir durum gibi gösterilmiştir. Tehdidin şekillerine (ceza, ölüm, aç bırakma) ayrıntılı bir şekilde yer verilmesi çocuklar için olumsuz bir durumdur. Okuduğu kitaplardan yola çlkarak gerçek hayatta benzer durumlarla karşılaşması durumunda tehdide başvurmayı seçenek olarak görebilir. Bu da eserin olumsuz yönünü oluşturmaktadır. Aşağıda tehdit etmeyle ilgili örnek cümlelere yer verilmiştir:

Öfkelenince tehdit etmek olası bir durumdur.

Bu sözler karşısında öfkeden deliye dönen Don Kişot herkese tehditler savurmaya başladı (Ç1: 41).

Kadın öfkeden deliye dönmüş̧ü. Onlara ağzına geleni söylüyor, tehditler savuruyordu (Ç1: 49).

Kimi zaman ölümle tehdit edilmektedir.

Yoksa bir adım ilerleyemez, mızrağımın ucunda can verirsiniz (Ç2: 15).

Kısa kes, diye bağırdı Don Kişot. Çabuk yerden kaldır beni, yoksa Dülsia’nın aşkı için seni öte dünyaya yollarım (Ç2: 17).

Arabaya sakladığınız prensesi hemen serbest bırakın, yoksa kargımla sizi delik deşik edeceğim (Ç2: 28).

Hain seyis, eğer bana hizmetlerin geçmemiş olsaydı be söylediklerinden dolayı kafanı uçurmam gerekirdi (Ç2: 48).

Ĕ̆er ölmek istemiyorsan, bu dediklerimi tekrar et dedi Don Kişot (Ç1: 57).

Şeytanın çocukları, arabaya zorla bindirip kaçırdığınız soylu prensesi hemen serbest bırakın; yoksa kötülüğünüzün cezasını çekersiniz, hepinizi öldürürüm (Ç3: 21).

Şimdi göreceksiniz gününüzü. Hepinizi gebertip zavallı şövalyeyi elinizden kurtaracağım (Ç2: 73).

Ben onu oraya hapsedenlere yapacağımı bilirim. Bakalım canlarını elimden nasıl kurtaracaklar? (Ç2: 72).

Ĕ̆er bu kavganin bitirilmesine izin verilmezse önüne çıkan herkesi öldüreceğini söyledi (Ç3: 23).

Teslim olmasını yoksa kafasımı uçuracağını söyledi (Ç3: 24).

Ĕ̆er dövüş şartlarnna uyarak, sizden istediğim itirafi yapmazsanız kendinizi ölmüş bilin (Ç3: 105).

Ya buyruğumu yerine getirirsin ya da bağırsaklarını deşer aslanlara yem ederim! diye bağırdı (Ç4: $54)$.

Ya hemen kapıyı açarsın ya da şuracıkta canımı alırım (Ç4: 54).

Pes etmeni istiyorum, aksi hâlde canını alacağım dedi (Ç4: 62).

Hileleriniz bana sökmez hain büyücüler, hepinizi geberteceğim! (Ç4: 69).

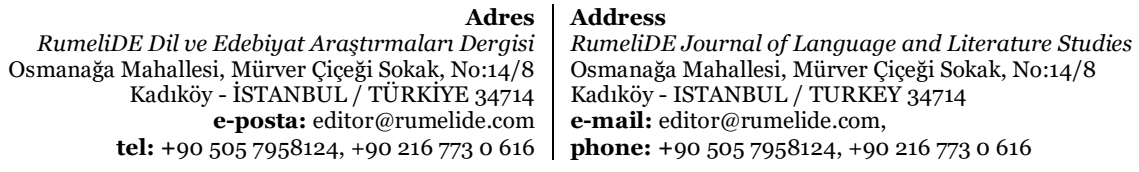


Bunu yapmazsanız benimle ölümcül bir savaşa girişmeye hazır olun bakalım (Ç5: 15).

Kimi zaman da dövmekle tehdit edildiği görülmektedir.

Çekil be adam, yoksa seni şimdi eşek sudan gelinceye kadar pataklarım (Ç2: 55).

Tehdit, karşısındaki kişi korkmaktadır.

Berber, Don Kişot’un tehditlerini işitince öyle korktu ki, eşeğinden inip son sürat koşmaya başladı (Ç1: $34)$.

Tehdit ederken seçenek sunulmaktadır.

Ĕ̆er dediğimi yapmayacaksanız, kendinizi savaşmaya hazırlasanız iyi edersiniz! (Ç1: 12).

Zorla alıkoyduğunuz prensesi hemen serbest bırakın! Yoksa kılıcımın tadına bakarsınız! diye bağırdı Don Kişot.

“Hemen açın şu kapıyı!” diye bağırdı Don Kişot sürücüye, "Yoksa ben açmasını bilirim!” (Ç1: 58).

Neler olacağım az önce söyledim. İsterseniz erkekçe tek tek gelin karşıma, dilerseniz her zaman yaptığımı gibi alçakça hepiniz birden... (Ç2: 16).

Ya açarsını kafeslerin kapısını ya da mızrakla mıhlarım (Ç2: 55).

Sancho’ya, parayı vermezse başına geleceklere katlanacağını söyledi (E: 29).

"Bak dostum, daha önce de seni uyarmıştım! Şu çırpıcı değirmeni sözünü ağzına alma. Yoksa yemin ederim ki seni eşeğin altına yuvarlarım.” (Ç3: 39).

Bir yandan da bağırarak tehditler savuruyordu. "Hey büyücüler, ya arabadaki tutsak güzeli burakırsınız ya da şuracıkta işinizi bitiririm (Ç4: 31).

Ya hemen çekip gidersin ya da cezanı çekersin (Ç4: 32).

Benim olan şeyi ya isteyerek verirsin ya da bileğimin gücüyle alırm (Ç3: 40).

Dulcinea del Toboso'nun dünyanın en güzel kadını ve Casildea de Vandalia'dan katbekat güzel olduğunu söylemediği an kendini ölmüş bilmesi gerektiğini bildirdi (Ç5: 78).

“Çabuk aç” diye bağırdı Don Kişot, "yoksa mızrağımla sizi şu kafese mihlarım” (Ç5: 82).

Mahvoldunuz şövalye, çatışmanın koşullarını kabul etmezseniz kendinizi ölmüş bilin (Ç5: 131).

Zorla kaçırmaya kalktı̆̆ııı asil prensesi derhal serbest burakmazsanız kendinizi ölmüş bilin (Ç5: 23).

Bunu kibarca ve kavgasız dövüşsüz yerine getireceğinizi umuyorum. Kabul etmeyecek olursanız, şu gördüğünüz mızrağım ve kulıcım sizleri yola getirmesini bilir (Ç5: 55).

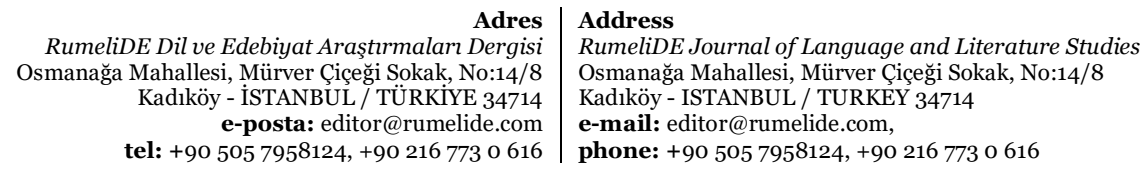


Tehdit kimi zaman aç bırakmakla yapılmaktadır.

Sancho, işin iç yüzünü öğrenmedikçe, ağzına bir lokma yemek bile koymayacağım (Ç3: 67).

Tehdit, ceza unsuru olarak görülmektedir.

Ne yapsanız boşuna! Briareos devi gibi kollarınızı sallasanız da cezanızı vereceğim (Ç3: 18).

“Eğer şövalye olmuş olsaydın, bu küstahlığınn cezasın çoktan görmüştün,” dedi Don Kişot (Ç3: 23).

Çık karşıma, senle tek başıma dövüşeceğim. Garamantaların krah Pentapolen'e haksız yere saldırmanın cezasımı vereceğim sana, dedi (Ç3: 35).

Aşağılık yaratıklar! Davranın bakalım! Kibrinizin bedelini ödeyeceksiniz! diye bağırarak ilk değirmene saldırdı (Ç1: 16).

Tehdit etme, haklı bir gerekçe olarak gösterilmektedir.

Gururu incinen Don Kişot, kattrcıyı sert bir dille uyard,, hatta onu tehdit etti (Ç1: 9).

“Anlaşıldı, bize zor kullanmaktan başka çare bırakmadınız.” dedi hancı (Ç1: 27).

Bu zındıklı̆ın bedelini fazlasıyla ödeyeceksiniz (Ç5: 16).

Tehdit eden kişinin ciddiye alınmadığı görülmektedir.

Değirmenciler kendilerine savrulan tehditlere ve kaba sözlere dikkat edemeyecek kadar meşgullerdi (Ç1: 62-63).

Don Kişot’un tehdit unsuruna sık başvurduğu görülmektedir.

Kahramanımız ayağa kalktı ve kılıcını sallayarak onlara tehditler savurdu (Ç1: 62).

Don Kişot, zor bela kendine geldiğinde hâlâtehditler savuruyordu (Ç2: 12).

Don Kişot, Senin dersini birazdan vereceğim (Ç2: 54) dedi.

Sancho, tehdidi lüzumsuz görmektedir.

Beni tehdit etmenizin gereği yok, dedi Sancho (Ç3: 5o).

\section{Fiziksel şiddet temasında yer alan kategoriler}

Fiziksel şiddet temasında yer alan kategorilere ilişkin bulgular Tablo 8'de sunulmuştur.

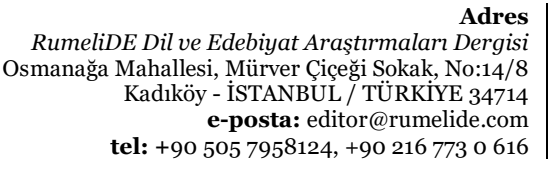

RumeliDE Dil ve Edebiyat Araştırmaları Dergisi Kadıöy - ISTANBUL tel: +90 505 7958124, +90 2167730616
Address

RumeliDE Journal of Language and Literature Studies Osmanağa Mahallesi, Mürver Çiçeği Sokak, No:14/8

Kadıköy - ISTANBUL / TURKEY 34714

e-mail: editor@rumelide.com,

phone: +90 5057958124, +90 2167730616 
Tablo 8. Fiziksel şiddet temasında yer alan kategoriler

\begin{tabular}{ll}
\hline & Dövmek \\
& Yaralamak \\
Fiziksel Şiddet & Vurmak \\
& Öldürmek \\
& Saldırmak \\
\hline
\end{tabular}

Dövmek unsuruna ilişkin bulgular, Tablo 9'da sunulmuştur.

Tablo 9. Dövmek unsuruna iliş̧in bulgular

\begin{tabular}{lll}
\hline & Eser & $\mathrm{f}$ \\
\cline { 2 - 3 } Dövmek & Ç1 & 5 \\
& Ç2 & 2 \\
Ç3 & 2 \\
Ç4 & 2 \\
Ç5 & - \\
Toplam & & 11 \\
\hline
\end{tabular}

Tablo 9'da eserlerde yer alan dövmek unsuruna ilişkin bulgulara yer verilmiştir. Dövmek unsuruyla ilgili toplamda 11 ileti mevcuttur. Dövmek iletisine yönelik en fazla ileti taşıyan eser Çı'dir. Bunu sırasıyla Ç2, Ç3 ve Ç4 izlerken Ç5’te ise dövmekle ilgili iletiye hiç yer verilmediği tespit edilmiştir. İncelenen eserlerde dövmek olumsuz bir ileti olarak öne çıkarken; dövüş anında kullanılan suç aletlerine yer verilmesi çocukların bu suç aletlerini kullanmaları konusunda onların özenmesine neden olabilmektedir. Eser bu yönüyle çocuklar için uygun değildir ve onları şiddete yönlendirebilecek unsurları taşımaktadır. Aşağıda dövmekle ilgili örnek cümlelere yer verilmiştir:

Dövüşün süresi belirtilmiştir.

İkinci yolcunun arkadaşları Don Kişot’u eşek sudan gelinceye kadar dövdüler (Ç2: 12).

Dövüşte suç aletleri kullanılmıştır.

Arkadaşlarmın dövüldüğünü gören bu kattrcılar Don Kişot’un üzerine saldırdılar ve onu taş yağmuruna tuttular (Ç1: 10).

Haydutlar onu taş yağmuruna tuttular; miğfer olarak kullandiğ bakır tası, şekli tamamen değişine kadar ezdiler ve onu iyice dövdükten sonra, zırhını çıkarıp üstünlüğünü çaldılar (Ç1: 41).

Oyuncular tek tek arabadan indiler, yerden taş topladılar ve Don Kişot'la dövüşmeye hazır hâlde suraya geçtiler (Ç1: 52).

Don Kişot’un kargısını elinden aldı, dizinde kırdıktan sonra Don Kişot’a bunun sopa gibi kullandiğı parçasıyla temiz bir dayak attı (Ç2: 17).

Öfkeyle atından indi, kargıyı alı dizinde ikiye böldü. Bir parçasıyla Don Kişot’u iyice dövdü (Ç4: 18).

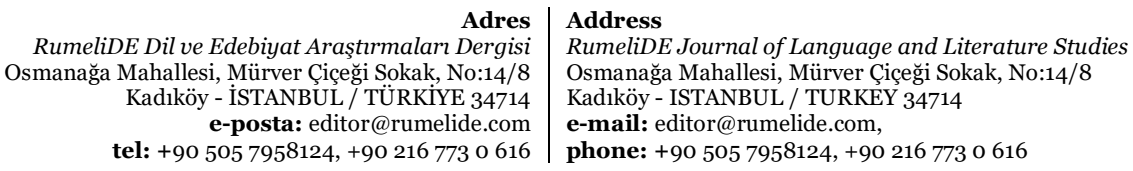


Dövüşün şiddeti hakkında bilgi verilmiştir.

Dövüş öyle şiddetli bir hâl aldı ki, etrafta onu izleyenler birinin öleceğine kesin gözüyle bakıyordu (Ç1: 19).

Don Kişot, keşişlerden birine öyle şiddetli vurdu ki, kendisi de yere yığlldı. Bir süre sonra Sancho da katıldı dövüşe (Ç1: 19).

Dövme eylemi detaylı bir şekilde açıklanmıştır.

Don Kişot’un arabadakilerle konuşmaya gittiğini görünce, Sancho'nun üstüne çullandılar, yere yıktılar. Bir güzel dövüp saçını başın yoldular (Ç3: 22).

Adamin zavallı bir kaçık olduğunu gördüğün hâlde actmadan dövdün (Ç4: 19).

Dövüş esnasında meydan okunmaktadır.

Kim olursa olsun, şeytanla bile dövüşmeye hazırım, diyordu (Ç3: 79).

Yaralamak unsuruna ilişkin bulgular, Tablo 10’da sunulmuştur.

Tablo 10. Yaralamak unsuruna ilişkin bulgular

\begin{tabular}{lll}
\hline & Eser & $\mathrm{f}$ \\
\cline { 2 - 3 } Yaralamak & Ç1 & - \\
Ç2 & 5 \\
Ç3 & 3 \\
Ç4 & - \\
Ç5 & 2 \\
Toplam & & 10 \\
\hline
\end{tabular}

Tablo 10'da eserlerde yer alan yaralamak iletisine ilişkin bulgulara yer verilmiştir. Toplamda 10 yaralamak iletisine ilişkin veri tespit edilmiştir. Yaralamak iletisine yönelik en fazla ileti taşıyan eser Ç2'dir. Bunu sırasıyla Ç3 ve Ç5 izlemektedir. Ç1 ve Ç4’te ise yaralamak iletisine hiç yer verilmediği tespit edilmiştir. İncelenen eserlerde yaralamanın hem insanlara hem de hayvanlara yapılabilen olağan bir durum olarak gösterilmesi ve yaralamanın organ kopmasına kadar ileri boyutta olması çocuklar için olumsuz örnek olmaktadır. Bu durum eserde karşılaştığı durumları gerçek hayatında uygulamasa bile çocuğun korkmasına neden olabilmektedir. Aşağıda yaralamakla ilgili örnek cümlelere yer verilmiştir:

Yaralamanın hangi suç aletiyle gerçekleştiği belirtilmiştir.

Aynı anda başına mızrağı yedi. Yaralanıp yere serildi (Ç2: 12).

İri bir taş Don Kişot’un kaburgalarmı birbirine geçirdi. Acıyla kuvranırken başka bir taş ağzının üstüne çarptı ve birkaç dişi ağzının içine düştü (Ç2: 43).

Kılhç koruyucunun başına öyle bir şiddetle indi ki adamcağızın burnundan, ağzından ve başından kanlar fışkırdı (Ç2: 30).

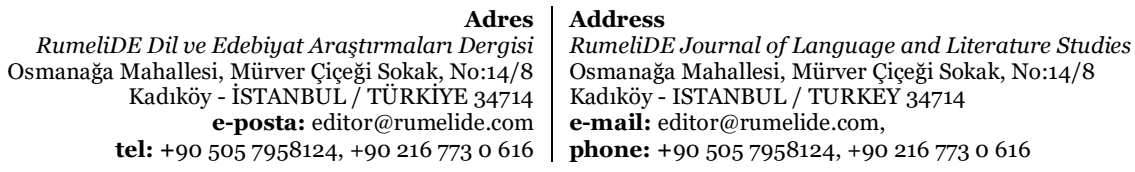


Piyero Usta, başını zor kurtardı. Neredeyse bir kılıç darbesiyle kanlar içinde yere seriliyordu (Ç2: 67).

Taş yağmuruna tutuldu ve iki taş göğsüne isabet etti. Don Kişot, ya öldüğünü ya da ağır yaralandiğını sandl (Ç3: 35).

Hangi organların yaralandığı belirtilmiştir.

Să̆ kolumun kesilmesine bile razıydım, dedi Don Kişot üzülerek. Yeter ki dişlerim kırılmasaydı (Ç3: 37).

Şiddete hayvanlar da maruz kalmaktadır.

Atın sirtı yarıya kadar soyulmuştu (Ç3: 18).

Yaralamanın ileri boyutta olduğu görülmektedir.

Kulağından bir parça kopartmaktan da geri kalmadı. Korkunç bir öfkeye kapılan Don Kişot adamın üstüne çullandı (Ç5: 25)

Karşılaşacağım ilk şövalyeyi kanlar içinde yere serdirdikten sonra atımı sana vereceğim (Ç2: 22).

Keşişlerden biri yaralanıp yere düştü (Ç5: 23).

Öldürmek unsuruna ilişkin bulgular, Tablo 11'de sunulmuştur.

Tablo 11. Öldürmek unsuruna ilişkin bulgular

\begin{tabular}{lll}
\hline & Eser & $\mathrm{f}$ \\
\cline { 2 - 3 } Öldürmek & Ç1 & - \\
& Ç2 & 1 \\
& Ç3 & 2 \\
Toplam & Ç4 & 1 \\
& Ç5 & - \\
\hline
\end{tabular}

Tablo 11'de eserlerde yer alan öldürmek iletisine ilişkin bulgulara yer verilmiştir. Toplamda 4 öldürmek iletisine ilişkin veri tespit edilmiştir. Öldürmekle ilgili en fazla iletiye Ç3’te rastlanmıştır. Bunu sırasıyla Ç2 ve Ç4 izlemektedir. Ç1 ve Ç5’te ise öldürmek iletisine hiç yer verilmediği tespit edilmiştir. İncelenen eserlerde 4 örnekten 3'ünün hayvanlara yapıldığı görülmektedir yani hayvana yapılan şiddetin normalleştirildiği söylenebilir. Son örnekte ise öldürme eyleminin çok kişi üzerinde yapılması insanları korkuttuğu için olumlu bir durum olarak gösterilmiştir. Eserin bu yönüyle çocuklar için uygun olmadığ 1 söylenebilir. Aşağıda öldürmekle ilgili örnek cümlelere yer verilmiştir:

Hayvanlar acımasız bir şekilde öldürülmektedir.

Koyun sürülerine saldırarak sanki en azılı düşmanlarıyla saldırıyormuşçasına önüne gelen zavallı koyun ve kuzuları öldürüyordu (Ç3: 35).

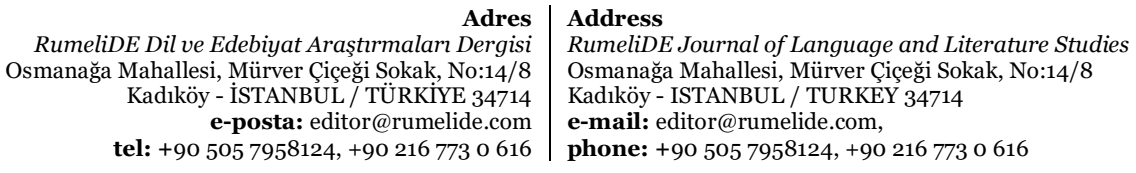


Önüne gelen koyunu şişlemeye başladı (Ç4: 43).

Bakın öldürdüğünüz yedi koyun şuracıkta (Ç2: 44).

Öldürme eyleminin şeklinden ve lakabın nasıl alındığı belirtilmiştir.

Meşe ağacından kocaman bir dal koparmış ve onunla o kadar çok Mağripliyi öldürmüş̧ü ki kendisine öldürücü lakabını takmışlar (Ç3: 19).

Saldırmak unsuruna ilişkin bulgular, Tablo 12'de sunulmuştur.

Tablo 12. Saldırmak unsuruna ilişkin bulgular

\begin{tabular}{lll}
\hline & Eser & $\mathrm{f}$ \\
\cline { 2 - 3 } Saldırmak & Ç1 & 6 \\
& Ç2 & 5 \\
Ç3 & 3 \\
Ç4 & 6 \\
Ç5 & 7 \\
Toplam & & 27 \\
\hline
\end{tabular}

Tablo 12'de eserlerde yer alan saldırmak iletisine ilişkin bulgulara yer verilmiştir. Saldırmak iletisine ilişkin 27 veri tespit edilmiştir. Saldırmak iletisine yönelik en fazla ileti taşıyan eser Ç5’tir. Bunu sırasıyla Ç1, Ç4, Ç2 ve Ç3 izlemektedir. Saldırmak (27) iletisinin bu kadar yoğun olması, öfke anında saldırmanın kaçınılmaz bir durum olması, gerek insanlara gerekse de hayvanlara yapılan şiddetin normalleştirilmesinin sonucudur. Eserin bu yönüyle çocuklar için uygun olmadığı söylenebilir. Aşağıda saldırmakla ilgili örnek cümlelere yer verilmiştir:

Saldırma eylemi gerçekleştirilirken suç aleti kullanılmıştır.

Don Kişot öfkeden deliye döndü. Düşmanına tüm gücüyle bir kez daha atıld ve bu sefer onu yere sermeyi başardı. Kılıcın adamın kafasına doğru savurduğu sırada, arabadaki kadın araya girdi ve ondan adamın canını bağışlamasını istedi (Ç1: 2O).

Yerde yatan şövalye kendine gelmeye başlamışken, Don Kişot elindeki kılıcı boynuna dayadı (Ç1: 56).

Adam Don Kişot’un omuz başına kılıcın öyle bir indirdi ki eğer zırhı olmasaydı Şövalye yaralanabilirdi (Ç2: 30).

Adamın gırtlağına kılıcın sivri ucunu dayayıverdi (Ç2: 30).

Arabacı arabayı sürecek olunca mızrağı karnına dayayıverdi (Ç2: 56).

Kılıcın çekip sahnedeki kuklalara saldırdı (Ç2: 66).

Mızrağıyla zavallı papazlardan birinin üzerine saldırdı. Adamcağız kendini yere atmasaydı belki de ölecekti (Ç3: 22).

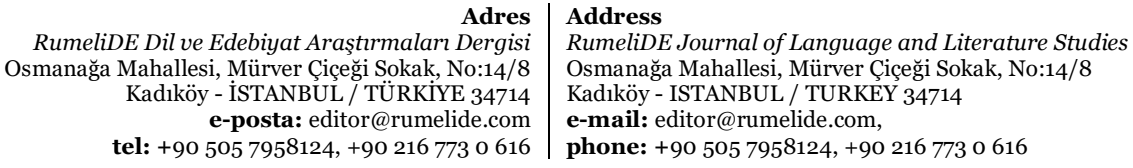


Düşmanının omzuna öyle bir kılıç darbesi indirdi ki kalkanı olmasaydı, şövalyemiz ikiye ayrlacaktı (Ç3: 23).

Öylesine öfkeyle saldırdı ki eğer kulıcı elinde ters dönmeseydi, bu darbe hem kavgaya hem de şövalyemizin serüvenlerine son verebilirdi (Ç3: 24).

Kılıcını çektiği gibi adamın üzerine yürüdü. Arabacı da kılıcın çekerek yere atladı. Biri atın sırtında, diğeri yerde korkunç vuruşma başladı (Ç4: 32).

Don Kişot, firsatı değerlendirdi ve kılıcını adamın boğazına dayadı (Ç4: 32).

Kılıcını adamın boğazına dayadı (Ç4: 62).

Don Kişot, kılıcıyla yerdeki şövalyenin boğazını dürttü (Ç4: 63).

Birden kılıcımı çekerek ortaya firladı ve "Canınıza susadınız anlaşılan" dedi (Ç4: 67).

Hemen atından inerek kılıcını Don Kişot’un boğazına dayadı (Ç4: 87).

Yerdeki mızrağı aldı ve kırdı, bu kırık parçalarla şövalyeye darbeler indirdikten sonra da gülerek uzaklaşmakta olan kafileye katıldı (Ç5: 16).

Don Kişot kılıcın çekip yük taşıyıcılarını üzerine saldırdı (Ç5: 32).

İsteğinin reddedilmesi karşısında büyük öfkeye kapılan Don Kişot, mahkûmlara karşı saldırıya geçti, bunun üzerine onlar da Don Kişot’u taş yağmuruna tuttu (Ç5: 57-58).

Değnekleriyle şiddetle saldırdılar (Ç5: 32-33).

Saldırma eylemi hayvanlara da yapılmaktadır.

Rozinante'yi atlarından uzaklaştırmak için değnekleriyle ona vahşice saldırdılar. Zavallı hayvancağız çaresizce yere serildi. Öfkeden deliye dönen Don Kişot kllıcina davrantp Rozinante'yi inciten adamlara saldirdı (Ç1: 22).

Saldırmak için sebep olmasına gerek yoktur.

Üzerlerinde giysileri olan bu insanlar cenazeye gidiyor gibiydiler. Fakat Don Kişot onlara da saldardı (Ç1: 31).

Adamlara ve önüne gelen ilk papaza saldırdı (Ç2: 28).

Öfke kontrolünün yapılamadığı belirtilmiştir.

"Bu bir hakaret!" diye haykurdı Don Kişot ve kendine engel olamayıp muhafiza saldırdı (Ç1: 39).

Saldırmanın şiddeti belirtilmiştir.

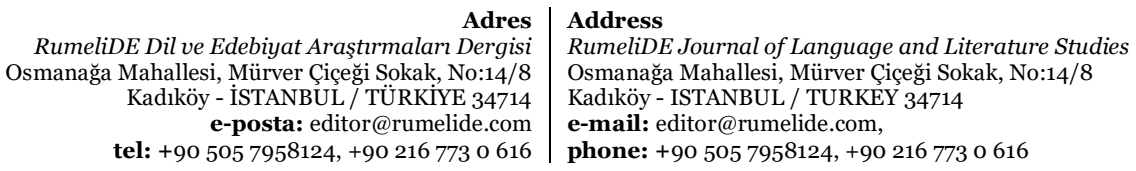


Beyaz Ay Şövalyesi atın süratle Don Kişot’un üzerine sürdü. Korkunç bir çarpışmanın ardından Don Kişot atından düşüp yere serildi (Ç1: 83).

Tehdit edici sözlerinin bir işe yaramadığın görünce sakaya ağır bir darbe indirdiği gibi yere serdi (Ç5: 11).

Sancho'yu bir darbede yere serdiler (Ç5: 23).

Adama saldırd, böyle bir saldırı beklemeyen muhafiz kendini yerde buldu. Bunun üzerine diğer muhafizlar saldırıya geçtiler (Ç5: 56).

Vurmak unsuruna ilişkin bulgular, Tablo 13’te sunulmuştur.

Tablo 13. Vurmak unsuruna ilişkin bulgular

\begin{tabular}{lll}
\hline \multirow{3}{*}{ Vurmak } & Eser & $\mathrm{f}$ \\
\cline { 2 - 3 } & Ç1 & 2 \\
& Ç2 & 1 \\
Ç3 & - \\
Ç4 & - \\
Ç5 & 2 \\
Toplam & & 5 \\
\hline
\end{tabular}

Tablo 13’te eserlerde yer alan vurmak iletisine ilişkin bulgulara yer verilmiştir. Vurmak iletisine yönelik en fazla ileti taşıyan eserler Ç1 ve Ç5'tir, ardından Ç2'dir. Ç3 ve Ç4’te ise vurmak iletisine ilişkin hiç veri tespit edilmemiştir. Vurma iletisinin derecesi, hayvana şiddet ve kullanılan suç aletleri çocuklar tarafından okunan kitaplarda yer alması olumsuz bir durumdur. Çocuğun okuduğu kitaplardan yola çlkarak konuşmak yerine şiddete başvurması, öfkesini kontrol etmek yerine şiddete meyletmesine neden olabilir. Eserin bu yönüyle çocuklar için uygun olmadığı söylenebilir. Aşağıda vurmak iletisiyle ilgili örnek cümlelere yer verilmiştir:

Vurma eyleminin derecesi belirtilmiştir.

Don Kişot tüm gücüyle adamın kafasına vurdu. Adamın canı öyle yandı ki, çı̆glıkları yeri göğü inletti (Ç1: 10).

Vurma eylemi gerçekleştirilirken suç aleti kullanılmıştır.

Mahkûmun bu kibirli konuşmasına öfkelenen bir muhafiz, ona sopayla vurmaya kalkıştı (Ç1: 38).

Vurma eyleminden hayvanlar da nasibini almaktadır.

Kargısı ile zavallı hayvanın arkasına vurarak onu uzaklaştırdı (Ç2: 57).

Atlarını, Rozinante'nin üstüne hızla sürdüler ve kırbaçlarıla hayvana öyle bir vurdular ki Rozinante iki seksen yere serildi (Ç5: 32).

Elindeki toplarla onu kamçladı, eşekçeğiz iyice korkuya kapıldı (Ç5: 69).

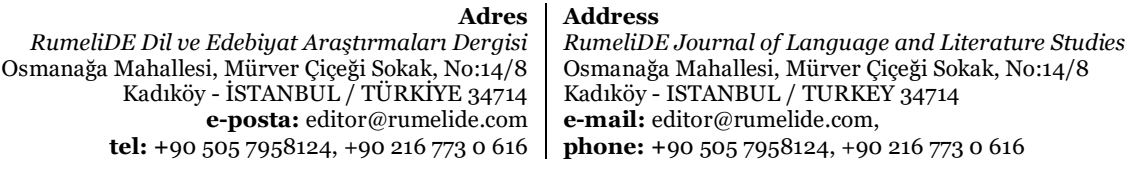




\section{Cinsel şiddet temasında yer alan kategoriler}

Cinsel şiddet temasında yer alan kategorilere ilişkin bulgular, Tablo 14’te sunulmuştur.

Tablo 14. Cinsel şiddet temasında yer alan kategoriler

\begin{tabular}{ll}
\hline Cinsel Şiddet & $\begin{array}{l}\text { Ilişkiye girmek } \\
\text { Çiplaklık }\end{array}$ \\
\hline
\end{tabular}

Cinsellik unsuruna ilişkin bulgular Tablo 15’te sunulmuştur.

Tablo 15. Cinsellik unsuruna ilişkin bulgular

\begin{tabular}{lll}
\hline & Eser & $\mathrm{f}$ \\
\cline { 2 - 3 } Cinsellik & Ç1 & - \\
& Ç2 & - \\
Ç3 & 1 \\
Ç4 & - \\
Ç5 & - \\
& & 1 \\
Toplam & & \\
\hline
\end{tabular}

Tablo 15'te eserlerde yer alan cinsellik iletisine ilişkin bulgulara yer verilmiştir. Cinsellik iletisine yönelik sedece bir ileti tespit edilmiştir. Bu da Ç3’tedir. Eserde cinsel iletinin kadının rızası olmadan gerçekleşmesi zorbalığa örnektir. Çocuklar tarafından okunan bir eserde cinselliğe yer verilmesi ve günlük hayatta bu tarz durumların olabilirliğini normalleştirmesi yönüyle olumsuzdur. Aşağıda cinsellik iletisiyle ilgili örnek cümleye yer verilmiştir:

Cinsel ilişki zorla gerçekleşmiştir.

Şu alçak yok mu, beni kırlarda yalnız görünce firsattan istifade ederek, namuslu bir kız için en değerli bir hazine olan iffetimi çald. Yirmi yıldan fazla bir zamandan beri koruduğum o hazineyi böyle sefil mi çalacaktı! (Ç3: 96).

Çpplaklık unsuruna ilişkin bulgular Tablo 16'da sunulmuştur.

Tablo 16. Çıplaklık unsuruna ilişskin bulgular

\begin{tabular}{lll}
\hline & Eser & $\mathrm{f}$ \\
\cline { 2 - 3 } Çıplaklık & Ç1 & - \\
& Ç2 & - \\
Ç3 & 2 \\
Ç4 & - \\
Toplam & Ç5 & - \\
\hline
\end{tabular}

Tablo 16'da eserlerde yer alan çıplaklık iletisine ilişkin bulgulara yer verilmiştir. Çıplaklık iletisine yönelik iletiye sadece bir eserde rastlanmıştır. O da Ç3’tür ve iki kez kullanılmıştır. Eserde başkasının yanında çıplak olmanın kitabın kahramanı Don Kişot tarafından normalleştirilmesi eserin olumsuz

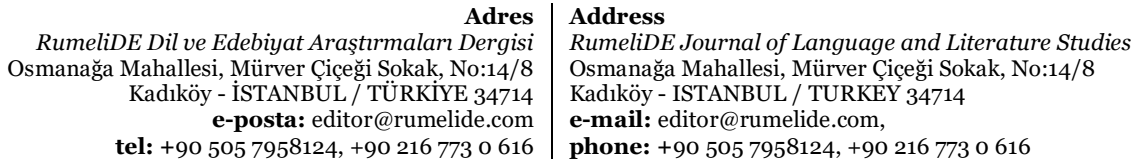


yönünü oluşturmaktadır. Çocuk kitaplarında bu tarz ögelerin yer alması olumsuz bir durumdur. Aşağıda çıplaklık iletisiyle ilgili örnek cümlelere yer verilmiştir:

Tablo 16'da incelenen eserlerinden sadece birinde çılaklık unsurunun yer aldığı tespit edilmiştir. Aşağıda çıplaklık ögesine ilişkin örnek cümlelere yer verilmiştir:

Soyunma işlemi birinin karşısında rahatça yapılmaktadır.

"Sancho, hiç olmazsa anadan doğma soyunayım ve bir iki çlgın hareket yapayım da bunları anlattığın zaman gözünle görmediğinden dolayı vicdan azabı çekmeyesin.” (Ç3: 48).

Söyler söylemez hemen soyundu ve bir iki takla attı, amuda kalkt. Bu hareketler strasinda öyle şeyler ortaya çıtı ki Sancho, artık efendisinin deli olduğuna bütün kalbiyle yemin edebileceğine inandı (Ç3: 49).

\section{Ekonomik şiddet temasında yer alan kategoriler}

Ekonomik şiddet temasında yer alan kategoriler Tablo 17'de sunulmuştur.

Tablo 17. Ekonomik şiddet temasında yer alan kategoriler

\begin{tabular}{ll}
\hline \multirow{2}{*}{ Ekonomik Şiddet } & Hırsızlık \\
& Yağmalamak \\
\hline
\end{tabular}

Hırsızlık unsuruna ilişkin bulgular Tablo 18'de sunulmuştur.

Tablo 18. Hirsızlık unsuruna ilişkin bulgular

\begin{tabular}{lll}
\hline & Eser & $\mathrm{f}$ \\
\cline { 2 - 3 } Hirsılık & Ç1 & 1 \\
& Ç2 & - \\
Ç3 & 1 \\
Ç4 & - \\
Ç5 & 1 \\
Toplam & & 3 \\
\hline
\end{tabular}

Tablo 18'de incelenen 5 eserin 3'ünde birer tane hırsızlık unsurunun yer aldı̆̆ı tespit edilmiştir. Ç2 ve Ç4’te hırsızlık ögesine ilişkin cümleye rastlanmamıştır. İncelenen eserlerde Sancho'nun çok aç olduğu için yiyecek torbalarını çalması gibi durumlar hırsızlı̆̆ın çocuklar tarafından normal bir durum gibi algılamalarına neden olmaktadır. Bu yönüyle eserin çocuklar için uygun olmadığı söylenebilir. Aşă̆ıda hırsızlık ögesine ilişkin örnek cümlelere yer verilmiştir:

Hırsızlık eyleminin kimin tarafından ve nasıl yapıldığı belirtilmiştir.

Sancho bu eşeğin üzerindeki yiyecek torbalarmı gördü ve hayvanın uzaklaşmasına firsat vermeden torbaları ele geçirdi (Ç1: 31).

Hırsızlık eyleminin kime yapıldığı belirtilmiştir.

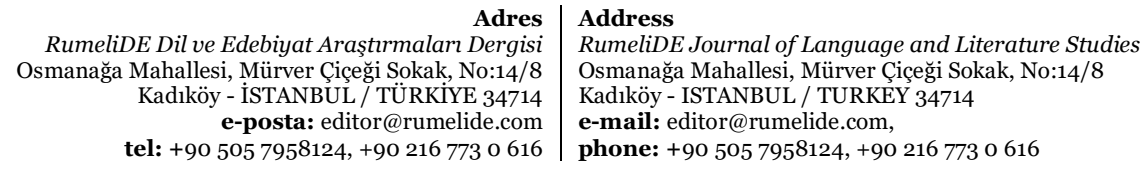


Sancho'ya neden rahibi soyduğunu sordular (Ç3: 22).

Neyin çalındığı belirtilmiştir.

Sancho'nun strtındaki pelerini de alp oradan uzaklaştılar (Ç5: 58).

Yağmalamak unsuruna ilişkin bulgular Tablo 19'da sunulmuştur.

Tablo 19. Yağmalamak unsuruna ilişkin bulgular

\begin{tabular}{lll}
\hline & Eser & $\mathrm{f}$ \\
\cline { 2 - 3 } Yağmalamak & Ç1 & 1 \\
& Ç2 & - \\
Ç3 & 1 \\
Ç4 & 1 \\
Ç5 & - \\
Toplam & & 3 \\
\hline
\end{tabular}

Tablo 19'da incelenen 5 eserin 3'ünde toplam 3 yağmalama unsurunun yer aldığı tespit edilmiştir. Ç1, Ç3 ve Ç4'te yağmalamak iletisine birer kez yer verildiği Ç2 ve Ç5’te ise hiç yer verilmediği tespit edilmiştir. Birinin malına zorla sahip olma düşüncesinin çocuklar tarafından okunan bir eserde yer alması olumsuz bir durumdur. Bu yönüyle eserin çocuklar için uygun olmadığı söylenebilir. Aşağıda yă̆malamak ögesine ilişkin örnek cümlelere yer verilmiştir:

Yağmalamanın kimin tarafından yapıldığı belirtilmiştir.

Haydutlar Sancho'yu da yağmaladıktan sonra birbirlerinden ayrllarak oradan kaçtılar (Ç1: 41).

Yağmalamak için bahaneler bulunmaktadır.

"Bu elbiseler benim sayılır", dedi Sancho. "Efendimin kazandığı savaşın ganimetlerini ahyorum." (Ç3: 22).

Bir şeye el konulması için yapılması gerekenler belirtilmiştir.

Hemen onunla vuruşmall, miğferine el koymahyım (Ç4: 40).

\section{Sonuç ve tartışma}

Don Kişot romanıyla ilgili farklı yayınevlerinde seçilen 5 kitap ayrıntılı olarak incelenmiştir. Çalışmanın sonucunda Don Kişot romanında şiddet unsurları duygusal, fiziksel, ekonomik ve cinsel şiddet olmak üzere dört temada toplanmıştır. Duygusal şiddet teması, alay etmek, hakaret etmek, intikam, küçümsemek ve tehdit olmak üzere beş; cinsel şiddet teması ilişkiye girmek ve çılaklık olmak üzere iki; ekonomik şiddet teması hırsızlık ve yağmalamak olmak üzere iki; fiziksel şiddet teması dövmek, yaralamak, vurmak, öldürmek ve saldırmak olmak üzere beş kategoride toplanmıştır. Eserlerde şiddetin yoğun olarak işlendiği ve en fazla duygusal şiddet temasıyla ilgili iletilere yer verildiği tespit edilmiştir.

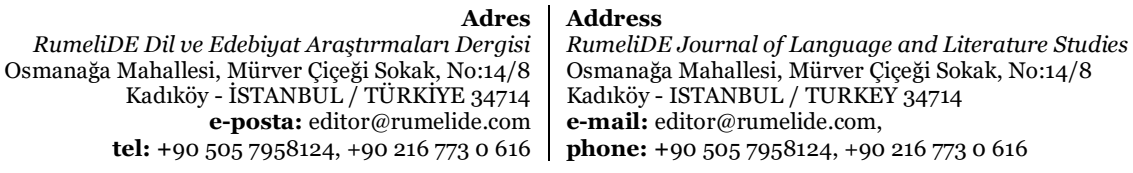


Duygusal şiddet temasında alay etmek (12), hakaret etmek (41), intikam (5), küçümsemek (23) ve tehdit (46) olmak üzere beş kategoride toplanmıştır. Bu temada en fazla tehdit teması, ardından hakaret, küçümsemek, alay etmek ve intikam kategorileri izlemektedir. Cinsel şiddet temasında ilişkiye girmek (1) ve çıplaklık (2) olmak üzere iki kategoride toplanmıştır. Ekonomik şiddet temasında hırsızlık (3) ve yağmalamak (3) olmak üzere iki kategoride toplanmıştır. Fiziksel şiddet temasında dövmek (11), yaralamak (10), vurmak (5), öldürmek (4) ve saldırmak (27) olmak üzere beş kategoride toplanmıştır.

Araştırmanın bulguları Alan (2020) tarafından yapılan çalışmanın bulgularıyla örtüşmektedir. Araştırmacı, Robin Hood isimli eserde yoğun bir şekilde şiddet ögesinin bulunduğunu ve şiddetin savaş, kavga, zorbalık şekillerinde kullanıldığı belirtilmiştir. Robin Hood ve arkadaşlarının her durumda şiddete başvurmasını kitabın olumsuz bir özelliği olarak gösterilerek şiddete başvurulmasının çocuk edebiyatı açısından uygun olmadığı belirtilmiştir. Şanal (2020) tarafından yapılan çalışmada incelenen kitapta şiddeti normalleştirici ifadelere ulaşılmış ve kitabın çocuğa görelik açısından uygun olmadığı sonucuna varılmıştır. Burç (2013) tarafından yapılan çalışmada Rifat Ilgaz’ın "Bacaksız’ın Başından Geçenler" adlı hikâye serisindeki eserler çocuğa görelik açısından incelenmiş ve araştırma sonucunda sözel ve fiziksel şiddet unsurlarına rastlandığı özellikle sözel şiddetin (lakap takma, aşağılama, dalga geçme) hat safhada olduğu sonucuna ulaşılmıştır. Bu sonuçlar araştırmanın bulgularıyla benzerlik taşımaktadır. Don Kişot romanında da hem fiziksel hem de duygusal şiddetin yoğun bir şekilde kullanıldı ̆̆ tespit edilmiştir. Yılmaz ve Destegüloğlu (2019) tarafından yapılan çalışmada çocuk kitaplarında şiddete ilişkin yansımalar tespit edilmeye çalışılmış, araştırma sonucunda gerek fiziksel gerekse de sözel şiddete yer verildiği ve şiddete en fazla çocukların maruz kaldığı sonucuna ulaşılmıştır. İlgili araştırmanın ve bu çalışmanın hedef kitlesinin aynı olmasına karşın şiddete maruz kalanlar farklıdır. Nitekim bu çalışmada şiddete maruz kalanlar kimi zaman hayvan, kimi zamansa yetişkin insanlardan oluşmaktadır. Ancak her iki çalışmanın araştırma konusu olan kitaplar çocuklar tarafından okunmaktadır ve şiddet barındırması olumsuz bir durum olarak göze çarpmaktadır. Karagöz (2018) tarafından yapılan çalışmada resimli çocuk kitapları incelenmiş ve araştırma sonucunda ilgili kitapların şiddet ve tehdit gibi olumsuz iletiler taşıdığı tespit edilmiştir. Don Kişot romanında da gerek fiziksel gerekse de duygusal şiddet ögelerinin fazlasıyla yer alması çalışmaların ortak yönünü oluşturmaktadır. Kayman ve Aydın (2021) da çalışmalarında Ömer Seyfettin’in “Ant” hikâyesindeki şiddet ögelerine ilişkin öğrencilerin görüşünü aldı̆̆ çalışmada, öğrenciler eserde şiddet içeren ifadelerden etkilendiklerini belirtmiştir. Bu çalışmadaki şiddet ögelerinin de çocukların psikolojilerini olumsuz etkileyeceği düşünülmektedir ve şiddetin detaylı şekilde sunulması eserin olumsuz yanını oluşturduğu söylenebilir. Çocuklar için hazırlanan eserlerde çocuk okurun, güzele, iyiye ve doğruya karşı duyarlığının güçlendirilmesi ve onun estetik deneyim kazanmasına olanak tanınması gerekmektedir (Çer, 2016b: 1401).

Yaşam gerçekliğinin bir sonucu olarak çocuk kitaplarında duygusal, fiziksel ve psikolojik şiddet yer alabilir ancak bu kitaplar çocuğa şiddetle nasıl başa çıkması gerektiğini öğretmelidir (Sever, 2008: 118). Karakter fiziksel şiddetle karşılaştı̆̆ı durumlarda bu sorunun çözümünde şiddeti kullanarak başarılı olmamalıdır (Çer, 2019: 9). Ancak Don Kişot romanında karakter, karşılaştığı her sorunda ilk olarak fiziksel şiddete başvurmayı tercih etmektedir ve elde ettiği başarıdan dolayı da takdir edilmeyi beklemektedir. Bu da çocukları şiddete teşvik etmektedir.

Dünya Çocuk Hakları Bildirgesine göre 18 yaşına kadar her birey çocuk kabul edilmektedir. Okudukları kitaplardaki kahramanları rol model olarak benimseyen çocuklar bazen olumlu bazen de olumsuz olarak etkilenebilmektedir. Okudukları kitaplardaki olumsuz iletilerden etkilenen çocuklar daha küçük yaş gruplarındakilerdir. Bu nedenle araştırma konusu olan Don Kişot romanının ilkokul öğrencileri

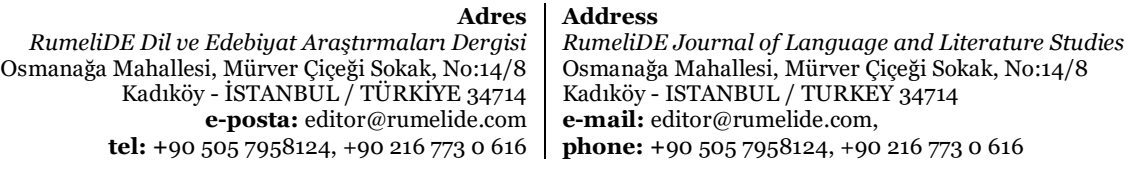


açısından olumsuz etkilere sahip olduğu ve bu yaş grubu için uygun olmadığı sonucuna varılmıştır. Araştırma sonucundan yola çıkılarak bu eserin ilkokul çocukları tarafından okunmaması önerilebilir.

\section{Kaynakça}

Abay, E. ve Tuğlu, C. (2000). Şiddet ve agresyonun nörobiyolojisi, Klinik Psikiyatri Dergisi, (3), 21-26.

Akkaş, İ. ve Uyanık, Z. (2016). Kadına yönelik şiddet, Nevşehir Hacı Bektaşi Veli Üniversitesi SBE Dergisi, 6(1), 32-42.

Alan, Y. (2020). Robin Hood isimli eserde çocuğa göre olmayan ögeler. Uluslarası Toplum Araştırmaları Dergisi, 16(28), 1296-1318.

Burç, B. (2013). Rıfat Ilgaz’n "Bacakszz’n Başından Geçenler" Adlı Hikâye Serisindeki Eserlerin Çocuğa Görelik İlkesi Açısından İncelenmesi. Yayımlanmamış Yüksek Lisans Tezi, Fırat Üniversitesi Eğitim Bilimleri Enstitüsü, Elazı̆̆.

Çer, E. (2016a). o-6 yaş çocuk kitaplarında çocuk gerçekliği ve çocuğa görelik. Ankara: Eğiten Kitap Yayınları.

Çer, E. (2016b). Türkçe öğretiminde çocuğa görelik ilkesine uygun edebiyat yapıtlarının önemi. İlköğretim Online, 15(4), 1399-1410.

Çer, E. (2019). Çocuk edebiyatı yapıtlarının çocuğa göre olmasını sağlayan başat bir değişken: eğitsel özellikler. Uluslararası Çocuk Edebiyatı ve Eğitim Araştırmaları Dergisi, 3(1), 1-11.

De Cervantes, M. (2019a). Don Kişot, Ankara: Fark Yayınları.

De Cervantes, M. (2019b). Don Kişot, İstanbul: Erdem Yayınları.

De Cervantes, M. (2019c). Don Kişot, İstanbul: Özyürek Yayıncılık.

De Cervantes, M. (2020). Don Kişot, Ankara: Masalperest.

De Cervantes, M. (2021). Don Kişot, Ankara: Arkadaş Yayınevi.

Demirel, Ş. ve Kökçü, Y. (2019). Richard Bach’ın Martı adlı eserinin çocuğa görelik bağlamında incelenmesi, Firat Üniversitesi Sosyal Bilimler Enstitüsü Dergisi, 29(2), 149-161.

Dilidüzgün, S. (1996). Çağdaş çocuk yazını. İstanbul: Yapı Kredi Yayınları.

Güleryüz, H. (2003). Yaratıcı çocuk edebiyatı. Ankara : Pegem A yayıncılık.

Kayman, F. ve Aydın, E. (2021). Ömer Seyfettin'in And adlı eserinde yer alan şiddet olgusuna ilişkin öğrenci görüssleri. Ana Dili Ĕ̆itimi Dergisi, 9(2), 416-429.

Küçük, E. E. (2005). İlköğretim 6., 7. ve 8. Sinfflarda Okutulan Türkçe Kitaplarındaki Düz Yazı Metinlerinin Çocuğa Görelik İlkesine ve Metinlerin İçerdiği Ĕ̆itsel İletilere Göre İncelenmesi. Yayımlanmamış Yüksek Lisans Tezi, Fırat Üniversitesi Sosyal Bilimler Enstitüsü, Elazığ.

Mavili Aktaş, A. (2006). Aile içi şiddet: kadının ve çocuğun korunması. Ankara: Elma Yayınevi.

Miles, M. B. \& Hubernar, M. A. (1994). Qualitative data analysis. Sage Publication.

Sever, S. (2008). Çocuk ve edebiyat. İzmir: Tudem Yayınları.

Sezer, K. (2020). Çiğdem Kaplangı'nın çocuk kitaplarının çocuğa görelik ilkesi açısından incelenmesi. Türkiye Bilimsel Araştırmalar Dergisi, 5(2), 347-359.

Şanal, A. (2021). Kral Şakir Serisinden "Mor Bir Fil Gördüm Sanki” adlı çocuk kitabının çocuğa görelik açısından incelenmesi. Mustafa Kemal Üniversitesi Ĕ̆itim Fakültesi Dergisi, 4(6), 64-90.

Şirin, M. R. (1998). Geçmiş zaman şarkaları. İstanbul: Diriliş Yayınları.

Yavuzer, H. (2009). Çocuk ve suç. İstanbul: Remzi Kitabevi.

Yıldırım, A. ve Şimşek, H. (2011). Sosyal bilimlerde nitel araştırma yöntemleri. Ankara: Seçkin Yayıncilık.

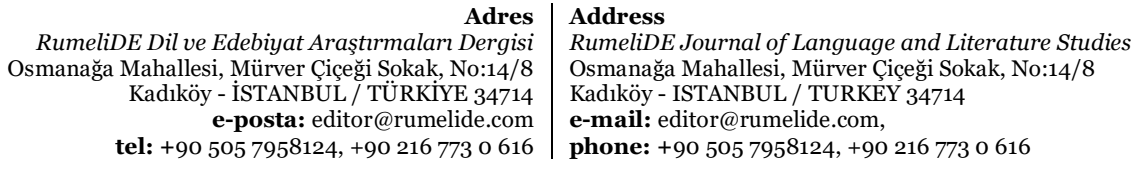


554 / RumeliDE Journal of Language and Literature Studies 2021.25 (December)

"Don Kişot" novel within the context of violence elements / T. Kaplan Alptekin (pp. 529-554)

Yılmaz, O. ve Destegüloğlu, B. (2019). Çocuk kitaplarına yansıyan şiddet. İlköğretim Online, 18(3), 1099-1112.

Adres | Address

RumeliDE Dil ve Edebiyat Araşturmalar Dergisi $\quad$ RumeliDE Journal of Language and Literature Studies Osmanağa Mahallesi, Mürver Çiçeği Sokak, No:14/8 Osmanağa Mahallesi, Mürver Çiçeği Sokak, No:14/8

Kadıköy - ISTANBUL / TURKIYE 34714 Kadıköy - ISTANBUL / TURKEY 34714

e-posta: editor@rumelide.com e-mail: editor@rumelide.com,

tel: +90 505 7958124, +90 2167730616 phone: +90 505 7958124, +90 2167730616 